\title{
Monitoring for GE Reflux: Is Normal the New Normal?
}

\author{
Mustafa Abdul-Hussein • Donald O. Castell
}

Published online: 25 November 2014

(C) Springer Science+Business Media New York 2014

Forty years have elapsed since Johnson and DeMeester's seminal studies on prolonged intraluminal esophageal $\mathrm{pH}$ monitoring [1] that led to the now popular notion of using ambulatory studies to detect abnormal gastroesophageal reflux (GER). Major technical diagnostic advances coupled with the evolution of highly effective acid suppressing medications have enhanced diagnosis and treatment of GER.

In this issue of Digestive Diseases and Sciences, Drs. Lin and Triadafilopoulos [2] describe their retrospective observations obtained from combined gastric and esophageal $\mathrm{pH}$ monitoring without impedance in 172 patients diagnosed with proton pump inhibitor (PPI)-responsive persistent heartburn or acid regurgitation. Despite being asymptomatic when receiving either a single $(43.6 \%)$ or double $(56.4 \%)$ PPI dose, $54.1 \%$ of the patients surprisingly had abnormal esophageal acid exposure (mean time $<\mathrm{pH} \quad 4=14.3 \% ; \mathrm{nl}=<8.2 \%$ ), indicating that gastric acidity is poorly controlled by PPIs and that gastric acidity correlates poorly with reflux symptoms. Since the technique of combined impedance $\mathrm{pH}$ measures all reflux episodes [3], it is predictable that use of this technique identifies more continuing reflux and opportunities for symptoms than does $\mathrm{pH}$-only-based monitoring. In the Lin and Triadafilopoulos study, some patients did report symptoms, including dyspepsia, which may well have been identified as heartburn or regurgitation by other patients. As an example, Rife et al. [4] from our laboratory reported

M. Abdul-Hussein $(\varangle) \cdot$ D. O. Castell

Division of Gastroenterology and Hepatology, Medical

University of South Carolina, Charleston, SC, USA

e-mail: abdulahu@musc.edu a wide variation of symptoms between patients and physicians, the understanding of which is essential to the interpretation of reflux symptoms.

Lin and Triadafilopoulos reported a very weak correlation $(R=0.011)$ between esophageal and gastric \% time $<\mathrm{pH} 4$ while receiving PPI therapy, entirely consistent with our results obtained with similar methods in 398 patients taking PPIs twice daily, in which we also reported very poor correlation $\left(R^{2}=0.11\right)$ between gastric and esophageal \% time $<\mathrm{pH} 4.0$ [5], reflected in the independent scatter between these two measures depicted in Fig. 1.

There are at least two simple explanations for these poor correlations. The first relates to the $\mathrm{pH}$ determination itself, which is a qualitative measure of acid concentration and provides no information on the quantity of acid present in the stomach. Thus, a $\mathrm{pH}$ of $<4$ could represent $5 \mathrm{ml}$ or 51 of such acidic material. It is well known that the volume of gastric contents is a major factor determining the potential for GER. Moreover, multiple factors feed into GER pathophysiology such as transient lower esophageal sphincter (LES) relaxations induced by gastric distention [6], mechanical factors related to sliding hiatal hernia, LES resting tone, obesity, gastric emptying, and esophageal peristalsis. Thus, it would be somewhat unreasonable to expect a strong correlation between gastric and esophageal $\mathrm{pH}$ values without accounting for esophageal motility abnormalities, hiatal hernia, or low LES pressure, which were not discussed by Lin and Triadafilopoulos. Another source of variability, as the authors pointed out, is that the patients did not consume standard meals, had varying lifestyles, and, most importantly, were treated with differing types and frequency of PPIs, since meal $\mathrm{pH}$, type of PPI, and frequency of PPI administration can affect \% time of esophageal and gastric $\mathrm{pH}<4$ [7]. 


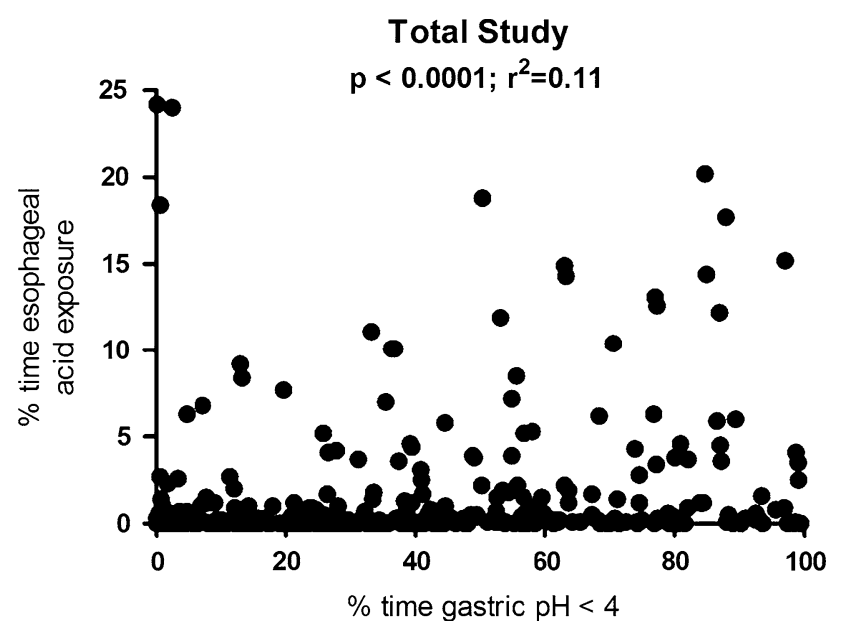

Fig. 1 Relationship between percent time of gastric $\mathrm{pH}<4$ and percent time of esophageal acid exposure

Ambulatory gastric $\mathrm{pH}$ measurement is, however, of value in assessing the need to adjust acid suppressive therapy. Of the 398 patients studied in our laboratory, $50 \%$ had gastric $\mathrm{pH}>4$ throughout the monitoring period, although one-third had variable periods at night with gastric $\mathrm{pH}<4$, a pharmacologic phenomenon typical of PPI therapy termed "nocturnal acid breakthrough," [8] readily controlled with the addition of a single dose of an histamine-2 receptor antagonist at bedtime [9]. A 24-h gastric $\mathrm{pH}>4$ indicates successful acid suppressive therapy.

The report by Lin and Triadafilopoulos provides important information on the effectiveness and limitations of acid control with PPI therapy [2]. Combined with our similar experience, it emphasizes the importance of monitoring gastric and esophageal $\mathrm{pH}$ during PPI therapy as a guide to therapy.

\section{References}

1. Johnson LF, Demeester TR. Twenty-four-hour $\mathrm{pH}$ monitoring of the distal esophagus. A quantitative measure of gastroesophageal reflux. Am J Gastroenterol. 1974;62:325-332.

2. Lin D, Triadafilopoulos G. Dual ambulatory $\mathrm{pH}$ monitoring in patients with gastroesophageal reflux rendered asymptomatic with proton pump inhibitor therapy. Dig Dis Sci. (Epub ahead of print). doi:10.1007/s10620-014-3324-y.

3. Vela MF, Camacho-Lobato L, Srinivasan R, Tutuian R, Katz PO, Castell DO. Simultaneous intraesophageal impedance and $\mathrm{pH}$ measurement of acid and nonacid gastroesophageal reflux: effect of omeprazole. Gastroenterology. 2001;120:1599-1606.

4. Rife C, Singh E, Castell D. The Variable Perception of Heartburn. Digestive Disease Week 2012. San Diego, CA; 2012.

5. Naas P, Rife C, Freeman J, Castell DO. A half acid therapeutic approach to reflux disease. ACG 2012 annual scientific meeting abstracts; Vol:107 PS38.

6. Dent J, Holloway RH, Toouli J, Dodds WJ. Mechanisms of lower oesophageal sphincter incompetence in patients with symptomatic gastrooesophageal reflux. Gut. 1988;29:1020-1028.

7. Katz PO, Gerson LB, Vela MF. Guidelines for the diagnosis and management of gastroesophageal reflux disease. Am J Gastroenterol. 2013;108:308-328.

8. Katz PO, Anderson C, Khoury R, Castell DO. Gastro-oesophageal reflux associated with nocturnal gastric acid breakthrough on proton pump inhibitors. Aliment Pharmacol Ther. 1998;12:1231-1234.

9. Xue S, Katz PO, Banerjee P, Tutuian R, Castell DO. Bedtime H2 blockers improve nocturnal gastric acid control in GERD patients on proton pump inhibitors. Aliment Pharmacol Ther. 2001;15: 1351-1356. 